\title{
Flood Vulnerability Mapping of River Ngadda Using Geospatial and Remote Sensing Techniques Maiduguri Metropolis, Borno State.
}

Oveka Obroh ( $\sim$ ovekaobroh@gmail.com )

Lincoln University, Canterbury, New Zealand.

Garba Sambo

University of Maiduguri, Borno, Nigeria.

\section{Research Article}

Keywords: Flood risk, Vulnerability, GIS

Posted Date: January 24th, 2022

DOI: https://doi.org/10.21203/rs.3.rs-1274069/v1

License: (c) (i) This work is licensed under a Creative Commons Attribution 4.0 International License.

Read Full License 


\section{Abstract}

Flood disaster has been threating to animal, plants, land, human and non-human resources over the years. This have increased concerns on the need to investigate various vulnerable areas to flood for decision making. As a mitigative measures to loss of lives, properties, and livelihood which could arise from flood disaster, understanding zones at risk to flooding is vital to support all stages of disaster management including early warning and planning. River Ngadda is a major river within Maiduguri metropolis. Its plains and banks are known to have different activities and resources. When the river overflows its shores, neighboring lands could suffer destruction, there could be loss of lives and properties. This project aims to investigate flood vulnerability along River Ngadda identifying the shores, plains, and banks of the river at risk. The research adopts ground truth information, the use of Aster DEM $(30 \mathrm{~m})$ and Sentinel $2(10 \mathrm{~m})$ Satellite Imagery dataset through Geospatial and Remote Sensing techniques to assess undulating nature of the area under study, identify areas liable to flood and analyzed the flood plain. Further analysis was carried out to obtain the Land use and Landcover (LULC) within the study area using a supervised classification and areas at various flood risk were also identified. This research results presented the river plains, flood vulnerable impact on LULC, it was found that 13.17 hectares of built-up areas fall within the very high flood risk zone, over sixty six percent $(66 \%)$ of the study area appears fall within the moderate to very high vulnerable flood risk zone and the production of the flood plains, LULC, risk and hazard map of the study area was presented. This result could aid early warning, planning and decision making for River Ngadda and its environs.

\section{Introduction}

River and its systems are very important to man. It is a natural resource which human cannot live without (Karr and Chu, 2000). In the historical times, the entire civilization grew around rivers which serve as a continent's circulatory systems (Karr, 1998). River and their adjacent floodplain corridors fulfill a variety of functions both as part of the natural ecosystem and for a variety of human uses. However, the rivers and its systems with its great positives also have negative effects when been altered or distorted, this could arise from nature such as excess rainfall, river overflow or human activities imposed on them thereby resulting to flood (Karr, 1998). Consequences of these changes such as river flow withdrawal; physical disturbance of riverbeds; river flow redistribution in time; river flow redistribution in space; and water clogging causes flood is oftentimes disastrous hence causing great damage (Govorushko, 2007).

Floods are very serious and frequent disaster occurring in many parts of the world. They are one of the most common natural hazards worldwide representing the most common global hazard causing phenomenal losses (Tingsanchali, 2012). Throughout human history, swelling rivers and floods have taken a heavy toll on properties and lives and caused more economic losses than any other hazard. River overflow and excessive rainfall from climate change, cause flood disaster into the river surrounding community hence large destruction of lives and properties. 
Gwange community within Maiduguri Municipal Council, has River Ngadda along the side of the community. Destructions from flood along the plains of River Ngadda has been recorded over the years. The main cause of river flooding is the occurrence of heavy rainfall during the raining season (Mala, Nyanganji and Mukhtar, 2012). Apart from climatic and hydrological phenomenon, the presence of natural or man-made obstructions in the path such as lack of drainage, floating debris, blocked drains, failure of different structures, over flown dam, causes flooding. Flooding, discharge of excessive water exceeding the channel capacity, and Flash floods, are the most pervasive and costly natural hazards faced by the habitants of Maiduguri.

\subsection{Flood hazards}

The problem of flood hazard is particularly prominent in the plains where the gradient of the river channel is very low (Mala, et al., 2012). Although, many scholars specifies that some river gradually gets dry during the dry season, but it is not uncommon to have floods in a city caused by excessive rainfall during the raining season (Nzeribe, et al, 2014).

The societies of developing countries are vulnerable to floods because of first, socioeconomic conditions in terms of poverty and lack of development (Mirza, 2003) second, most of the dams in developing countries are not multipurpose (Oruonye, 2015).; third, during floods, planning, design and implementation of the measures are inadequate and ineffective fourth, rural areas depend heavily on agriculture and are generally more affected than urban areas; fifth, lack of education; sixth, lack of nonstructural measures; and lastly, there is a lack of adequate human and material resources to tackle the massive disaster-like floods that occurred in the past (Mirza, 2003; Balica, Dinh, \& Popescu, 2015). Because of their vulnerability often millions of peoples become homeless, and hundreds of thousands are in need for food and medicines (Ahmad, 2003).

In Nigeria, Alau dam constructed on River Ngaddabul (Daura, Gisilanbe and Waziri 1997); caused flooding which emerged from a heavy rainfall of 12th to 13th September 1994. This led to a human displacement in different parts of Northern Nigeria, having Maiduguri town as one of the most affected locations. According to Nigeria Floods Sep 1994 UN DHA Situation Reports over 400000 displaced and homeless persons of which 180,000 were in immediate need for accommodation. Destructions of properties recorded from the flood include houses, roads, communication routes and shutdown of network providers, contamination of water, increase in health deterioration, damage of livestock and large hectares of farmlands. Unplanned areas of poor habitation systems and facilities within the flood plains of the metropolis were most affected by the flood presenting a rise in economic draw back (Mala, Nyanganji and Mukhtar, 2015).

Floods as identified as one of the most common natural disasters that looms the world has been estimated by Dilley et.al 2005 in Bhuiyan, (2014) as having more than one-third of the world's land area to be flood pone and affecting over eighty percent of the world's population. 
Flood hazard mapping is a vital component for appropriate planning in flood prone areas. It creates understandable charts and maps which aids planning and decision-making during identification of risk Bapalu, and Sinha, (2005), in addition, it facilitates prioritization of mitigated efforts and response plans (Emmanuel Udo, Ojinnaka, Baywood, and Gift, 2015; and Forkuo, 2011).

Investigating flood vulnerability along the rivers is very crucial in disaster planning and management. In recent years the impacts of floods have gained importance because of the increasing amount of people, economic activities and ecosystems that are impacted by its adverse effects (Jonathan, et al., 2020).

\subsection{Flood Vulnerability Mapping}

Development of flood vulnerability map in arid areas is a significant issue that needs to be addressed. Areas surrounded by rivers are more of a concern mostly because that large amount of rain fall, and flow of water could cause flood. In years 1995 and 2015, floods were estimated to represent about $43 \%$ of all weather-related catastrophes, reaching more than 3,000 documented events of 157,000 loss of lives and estimated minimum economic losses worth US\$ 662 billion (Wahlstrom and Guha-Sapir 2015 in Kabenge, et al, 2017). Their widespread existence and destruction drives scientists to investigate this phenomenon thoroughly.

To foster easy management and planning of flood disaster and monitoring, various approaches have been used in mapping out flood prone areas of which the recent technology has been seen in the use of remote sensing and GIS techniques.

The first integration of remote sensing with flood monitoring mentioned in literature dates to the 1970s, where data from Landsat 1 helped to analyse the Mississippi flood of 1973 (Deutsch and Ruggles, 1974). Since then, scientists have continued to use satellite data as auxiliary sources for multiple reasons, e.g., change detection, or observation of flood boundaries (Moore and North, 1974; Jeyaseelan, 2003; Bello and Aina, 2014; and Klemas, 2015)

Remote sensing is widely used in all stages of disaster management, from the mapping of flood-prone areas, through flood detection, early warning, evacuation planning, damage assessment and spatial planning (Jeyaseelan, 2003; Bello and Aina, 2014; Klemas, 2015). Various remotely sensed data and approaches have proven effective for disaster planning and responses. The combined passive and active remote sensing systems presented flood damage of urban, rural, and infrastructural categories, in which remotely sensed Landsat data was critical in flood stimulation and loss estimate in Japan (Dutta and Herath, 2001).

According to Wang, and Xie, (2018); and Jeyaseelan, (2003), remote sensing provides critical data for mapping water resources, measuring hydrological fluxes, monitoring drought and flooding inundation, while geographic information systems (GIS) provide the best tools for water resources, drought, and flood risk management. It creates understandable charts and maps which aids planning and decision-making during identification of risk in addition, it facilitates prioritization of mitigated efforts and response plans (Emmanuel et al.,2015; and Forkuo, 2011). 
Bangladesh flood hazard mapping research approach with the use of NOAA AVHRR data and Geographic Information Systems (GIS) resulted in the production of flood hazard maps. The research focused on the use of depth of flooding and duration of flooding for assessment, prediction and analysis obtained from the satellite images. Imrul (2006) in his findings on Bangladesh flood research, emphasized on the remote sensing and GIS supported for early warning and complete disaster risk management cycle. Delineating the flood prone areas in the Tapi catchment of India was well achieved with the use of Digital Elevation Model (DEM), GPS data, IRS-1DLISSIV satellite imagery, river hydraulic analysis and geospatial technologies (Singh \& Sharma, 2009).

The expected damages and produced risk map of river flood for Dhaka East was conducted with information derived from water level and discharge records, topographic maps, land use map, secondary depth duration-damage function, and the monetary value of land use specific property (Gain \& Hoque, 2013). The vector-based digital terrain model (DTM), Triangulated Irregular Network (TIN) was developed for the study area by digitization of the contour lines and point elevations using ArcGIS 9 for flood inundation mapping with the HEC-RAS simulation.

In a similar way, Chen, Ito, Sawamukai and Tokunaga, (2015) investigation on flood hazard assessment emphasized on flood hazards in Kujukuri Plain of Chiba Prefecture, Japan. In the research, flood management and environmental protection sector gained from leveraging on using a multi-criteria decision analysis and GIS techniques incorporating six factors of river system, elevation, and depression areas in the research.

Flood risk is a combination of threat, consequence and vulnerability identifying functions of green infrastructural landscapes (Carter, Handley, Butlin \& Gill, (2018). Its management and adaptation of cities to climate change disaster management and planning within some certain jurisdictions and distant locations some areas liable to flood could be managed through green infrastructural development. Gain and Hoque (2013) argument was supported with the findings which showed that to achieve flood risk of a location, the success could be attributed to a combination of Geospatial technologies modelling the surface water run-off and the DTM within the boundary area under study (Carter, et. al., 2018).

Just like other parts of the world, research have been carried out in Nigeria on flood and its effect in various parts of the country, unfortunately Maiduguri has had few research studies on risk mapping and flood vulnerability as well as its impact on lives and properties using geo spatial techniques. The research earlier conducted appears to have larger coverage or scale with little or no concentration towards a particular the section of River Ngadabul close environs hence recommending improved and updated investigation using better technologies.

Mala, et al., (2012) considered a research on gully development along river Ngaddbul flood plain of Maiduguri, their approach utilised measurements of gully length, width, and depth at four locations. The results showed that Ngaddabul annual flood, rainfall amount, runoff taking advantage of footpaths, wheeled-tracks, soil texture and human factors could cause gully development, erosion and flood without identifying built up areas liable to flood. 
Some other researchers have considered assessment of flood within Maiduguri and its environs using different methodology. Jimme, Bashir and Adebayo (2016) studied the Spatial Distribution Pattern and Terrain Analysis of Urban Flash Floods and Inundated Areas in Maiduguri Metropolis. His study used data generated from Shuttle Raddar Topography Mission and findings presented low lying locations within the study area, identifying potential areas liable to flash flood with a conclusion on recommendation on a continued vulnerability mapping improved which this research will provide.

Similarly, Kaka, Mayomi and Daura's research in (2019) found that the Topography plays a great role on Flood Vulnerability in Maiduguri using a 30m Asterdem Data. Recommendations made were on priority consideration given to areas liability to flood during disaster response and further studies on vulnerable areas which this research is aimed at using higher resolution imagery.

In this study, application of Remote Sensing (RS) and Geographic Information System (GIS) techniques will be applied using Sentinel dataset of $10 \mathrm{~m}$ resolution and a $30 \mathrm{~m}$ Aster DEM of the study area compared to previous studies and in line with recommendations from earlier researchers to explore flood vulnerability mapping within the study area. Vulnerability assessment for settlement and other land use would be identified enhancing the results obtained of different structures and facilitates prone to damages caused by flood generating of a flood risk mask (a map layer showing the extent of flood impact upon occurrence) and ready to be distributed to disaster management authorities.

Hydrologic analysis will be combined with socioeconomic resources and constraints with the help of GIS data processing software ArcGIS 10.4, Sentinel, imagery at a specific resolution used to detect change in river morphology and to identify flood plains. DEM will be incorporated into the software for flood elevation estimates and risk map zones identified.

Primary data on past hazards, socio-economic condition, vulnerability, response capability in the recent past would be collected to develop vulnerability and risk map. This study therefore identifies vulnerable areas, flood plains and risk zones of within the study area.

\section{Study Area}

River Ngadabul is located within the Metropolis of Maiduguri Local Government Area of Borno state located at the North eastern part of the country was the study site as shown in Figure 2.1.

River Ngadda originates from River Yedzaram and Gadombole which meet at Sambisa both in Nigeria and flows as River Ngadda into Alau Dam and stretches down across Maiduguri Metropolis then emptied into Lake Chad (Nyanganji 2009; Bakari, Akunna, and Jefferies, 2014; Bukar, Oladipo, Ibeanu, and Zakari, 2016a; Bukar, Oladipo, Ibeanu, and Zakari, 2016b; Bukar, Oladipo, Ibeanu, and Zakari, 2016c).

\subsection{Materials and Method}

- Laptop 16.0 GB RAM of 64 bit Operating System, x64- based processor 
- Global Positioning System (GPS)

- Sentinel-2

- Aster DEM

- ArcGIS (ArcMAP) 10.8

With the use of the listed equipment and data, the approach adopted is shown in the Flow Chart of Section 2.2.

\subsection{Flow chart}

The flow chart (see Figure 3.2) presents an overview of the methodology adopted

\subsection{Data Collection}

Mixed method of data collection was done. While primary data was collected on the field upon site visitation, elevation coordinate of areas where flood had been experienced in the past was obtained and noted, overview of the area was also noted. The complete dataset for the research was obtained from secondary sources.

Sentinel 2 imagery from Copernicus Open Access Hub for the study area was extracted defining the criteria of 2021 Sentinel-2A satellite imagery with a Multi-spectral instrument. This was further sorted by sensing date, product type, cloud cover of ranges zero through to six (0-6.0). With the criteria set, the imagery of June 10th, 2021 Sentinel 2A Satellite imagery with a cloud cover percentage of 0.001669 and 0.0 cloud shadow percentage was extracted.

Similarly, AsterDEM of $30 \mathrm{~m}$ resolution with a minimum elevation of the study area was obtained

\subsection{Data Processing}

\subsubsection{Sentinel-2}

Upon obtaining the dataset, a supervised processing was carried out using ArcGIS software. Although the imagery had a reflectance of $60 \mathrm{~m}$. The Sentinel-2,10m resolution dataset of Band 2,3,4 and 8 were the appropriate bands for the research. The obtained imagery was inputted into the map interface presenting its natural color, the study area was clipped using the Geoprocessing tool. Further processing of band combination was carried out to present the false color combination for easy interpretation (See Figure 2.3). This gave rise to the next training samples for land use land cover classification.

A schema was created, and the different sample classes were specified with the conventional colors. Using the polygon feature type, the samples were further trained for the different classes, merged, collapsed, and reclassified. The data was classified into four various land uses and land cover types after adopting the supervised training model. 


\subsubsection{AsterDEM}

Furthermore, the AsterDEM raster was of 30m resolution with a minimum elevation of 296 meters and a maximum of 327 meters. The study area was first clipped, further processing and reclassification was performed on the data set to obtain actual range values and classification for Digital Elevation Model of the study area. This was also guided but the obtained primary field data of the study areas where flood had been experienced in the past to aid the production of Flood plain Map and Flood prone areas.

\section{Analysis And Results}

In line with the objectives of this research, the analysis was carried out using a multi-criteria approach. Data management tool and spatial analytical tool to identify Flood risk areas and Flood plains. This further transcended to identifying flood risk zones within the study area and built-up areas at very high risk were identified.

\subsection{DEM and Flood plain Analysis}

Statistical data clustering of the Jenks optimization method was adopted for the analysis. Jenks Natural breaks of the study area was performed in which the sum of squared deviations for array means (SDAM) and sum of squared derivation for class means (SDCM) was derived to obtain its Goodness of variance fit (GVF) whose value lies between 0 through to 1 .

$G V F=(S D A M-S C D M) / S D A M$

The above method resulted to a reclassification of the DEM of which a customize extension activated and a good color ramp was chosen.

Similar procedure was used for the identification of different plains and flood risk areas. This procedure generated a grid codes, counts and values for both themes.

\subsection{Flood Risk}

Again, with the same spatial analytical method, the grid code was generated for the flood risk areas. The obtained grid code was given appropriate symbology to produce a risk map (see Figure 3.3).

\subsection{Flood Risk Zone}

Furthermore, the flood zone was cross tabulated, the map algebra and raster calculator performed different functions during the spatial analysis. The includes the use a multiplier with the results (grid codes/ values) obtained from topographic analysis and flood risk areas to map out vulnerable flood risk zones (see Figure 3.4).

Flood plain / Flood Topo Risk area =Flood Risk Zone (Vulnerability) 
This analysis presented grid codes shown in Table 3.1 and classified into five (5) Flood Risk Zones using the common vulnerability scoring system and severity level.

Table 3.1

Grid code of Flood risk zones and the identified classes of River Ngadda

\begin{tabular}{|llll|}
\hline $\begin{array}{l}\text { Flood risk grid } \\
\text { code }\end{array}$ & $\begin{array}{l}\text { Flood plain grid } \\
\text { code }\end{array}$ & $\begin{array}{l}\text { Flood risk zone grid } \\
\text { code }\end{array}$ & Flood risk zones \\
\hline 1 & 1 & 1 & Very Low Flood Risk Zone \\
\hline 2 & 2 & 4 & Low Flood Risk Zone \\
\hline 3 & 3 & 9 & Moderate Flood Risk Zone \\
\hline 4 & 4 & 16 & High Flood Risk Zone \\
\hline 5 & 5 & 25 & $\begin{array}{l}\text { Very High Flood Risk } \\
\text { Zone }\end{array}$ \\
\hline
\end{tabular}

SQL (structural query language) expression was a determinant for the area of flood risk zones (See Table 3.2).

Count $x$ Pixel Area $=$ Area in Sq. $m\left(m^{2}\right)$ Where the pixel area is $30 \mathrm{~m}$ by $30 \mathrm{~m}$

Table 3.2

Area of flood vulnerability zones of River Ngadda

\begin{tabular}{|llll|}
\hline Flood risk zone & Flood plain & Flood risk zones & Area (hectares) \\
\hline Very high flood risk & Low plain & Very High Flood Risk Zone & 130.23 \\
\hline High food risk & High plain & High Flood Risk Zone & 199.8 \\
\hline Moderate flood risk & Lowland & Moderate Flood Risk Zone & 235.71 \\
\hline Low flood risk & Upland & Low Flood Risk Zone & 231.03 \\
Very low flood risk & Highland & Very Low Flood Risk Zone & 60.21 \\
\hline
\end{tabular}

This area of each flood vulnerability risk zone was further analyzed and presented in its percentage as shown in Figure 3.5 using the formula below

(Flood risk zone / Total flood risk zone) x 100

From the above, it is apparent that more areas within the study area is liable to flood and over $50 \%$ lies between the moderate to very high risk which expresses concerns of which activities or settlement should not be permitted.

\subsection{Land use Landcover and Flood zone}


Having identified zones vulnerable to flood and area determined, the Land use Land cover raster (see Figure 3.6) was vectorized. The built-up areas only were geo-processed and its intersection with the Very high flood risk zones upon overlay (see Figure 3.7) was determined and the area was calculated (see Table 4.5).

Table 3.3

Area of built up within the Very high flood risk zone of River

Ngadda

\begin{tabular}{|lll|}
\hline Land use Land cover & Area in sqm & Area in hectares \\
\hline Built up & 131667.83 & 13.17 \\
\hline
\end{tabular}

\section{Discussion}

River Ngadda and its environs understudy presented an interesting and concerning output from its analysis. It was apparent that the procedures used for this research as described by and Jeyaseelan, (2003) stood as a good approach to obtaining the aim of the research.

The objective of assessing the undulating nature of the area of interest, was met, and used for further analysis, this supports Forkuo (2011) argument, which in turn was concurred by Emmanuel et al., (2015) in their opinion stating that analytical output from the assessment could support planning and prioritization efforts to mitigation and response.

This research findings agree with Mala, et al., (2012) argument specifying that areas of low or very low plain are risk to flood especially during the period with high amount of rain fall. About $30.51 \%$ within the study area lie on the low and very low plain of high flood risk and very high flood risk where different activities are ongoing, and infrastructure are present while $7.03 \%$ lies on the highland of very low flood risk (see Figure 4.5). This implies that the greater percentage of the study area is at risk and requires adequate attention.

Furthermore, the area estimation of each flood zones analyzed for and as shown in Table 4.4 and Table 4.5 respectively shows the extent of possible damage when a flood occurs as well as resources that could be lost using satellite imagery spatial analysis described by Blasco, Bellan, and Chaudhury, (1992) and in same argument by Brouder (1994) and Demir and Kisi, (2016). While Table 4.4 presents area in hectares for each zone, Table 4.5 in similar way identified that 13.17 hectares of built-up areas could be affected by flood upon its occurrence.

In addition, analyzing flood risk impact on various land use land cover presented the different classes of built-up, vegetation, water, and bare land at different risk zones. This, in addition to the area extent obtained as described above, fostered understanding of which natural and human resources lie within the study area and to what extend will the built-up areas be affected within the very high flood risk zone (see Figure 4.7) 
Identifying resources present within the study area also could aid the understanding of possible economic and social infrastructure which could be lost at the occurrence of flood hazard (see Figure 4.6) this supports Horritt et al., (2003) argument on the possibility of the detection of flooded vegetation or vegetation prone to flooding using remote sensing techniques.

Lastly, the development of the vulnerable risk maps, and flood plain maps from the multicriteria approach and analysis adopted using various distinct color composite as argued by Rasid and Pramanik, (1990) shown in figure 9 and figure 14 presents a simple, explicit, coherent, and logical comprehension on zones of flood risk for early warning and complete disaster risk management cycle.

\section{Summary}

The River Ngadda and its surrounding plains from this research has increased body of knowledge to support disaster risk management processes, ranging from early warning planning, response, rescue, rehabilitation, and relocation. The multi-criteria approach of Chen,et al., (2015) proved relevant for flood vulnerability mapping.

This research further presents an in-depth knowledge of the study area which could be referenced by researchers for further study or analysis of the area of interest.

In addition, planners involved in land use and construction works could benefit from this study as it poses to be a document to support required information for development purposes.

\subsection{Recommendations}

Medium and low flood risk zones where drainage system or water flow system is not available, should have individuals discouraged from residing within those locations or implement any livelihood activity ongoing as flood water from high-risk zones could possibly overflow there by constituting negative impact within that zone.

Flood plain regulations should be established, existing flood plain laws should be enforced and adhered to as a measure to reduce adverse river flood impact.

Tree planting and afforestation could be encouraged within river plains as a measure to reduce velocity of river flow in turn support sustainable soil land conservation and management.

Adoption to Land use planning or recharacterization of the vulnerable areas, construction of drainage system, flood control embarkments, and dredging works could be a measure to support reduction of flood impact within the study area.

Lastly, it is recommended that further research could be carried out with a different methodology and additional information analyzed for comparison purposes or extended areas for a wholesome comprehension, in-depth and wider coverage on Ngadda riverbanks, boundary, and plains. 


\subsection{Conclusion}

From the research findings, it is apparent that flood has an impact in the society and understanding the nature of the terrain especially within riverbanks and its environs is paramount to avoid destruction of properties and save lives. Resident including their lives and properties that lies on areas prone to flooding are at great danger regardless of their vulnerability status, this is especially because flooding cannot be completely avoided but its effects reduced.. If appropriate authorities do not give adequate attention and prepare for any future flood occurrence, it will have great impact on human and non-human resources. Lives and livelihood could be lost, and properties damaged which would present a setback in the socioeconomic status within the environs and state at large.

In conclusion, the relevance and applicability of this research extends to the effectiveness and efficiency of the use of GIS and Remote sensing technologies for disaster risk management as its finding and produced maps could be relevant as a vital tool for early warning, planning, decision-making purposes, researchers, and other appropriate authorities.

\section{References}

Ahmad, K. (2003). Floods in Pakistan leave many dead or homeless. The Lancet, 362(9383), 542.

Balica, S. F., Dinh, Q. and Popescu, I. (2015). Vulnerability and exposure in developed and developing countries: Large-scale assessments. In Hydro-meteorological hazards, risks, and disasters (pp. 125-162). Elsevier.

Bapalu, G. V. and Sinha, R. (2005). GIS in flood hazard mapping: A case study of Kosi River Basin, India. GIS Development Weekly, 1(13), 1-3.

Blasco, F., Bellan, M. F. and Chaudhury, M. U. (1992). Estimating the extent of floods in Bangladesh using SPOT data. Remote Sensing of Environment, 39(3), 167-178.

Bello, O. M. and Aina, Y. A. (2014). Satellite remote sensing as a tool in disaster management and sustainable development: towards a synergistic approach. Procedia-Social and Behavioural Sciences, 120, 365-373.

Brouder, J. A. M. (1994). Flood study in the Meghna-Dhonagoda polder, Bangladesh. Proc. Asian Institute of Remote Sensing).

Carter, J. G., Handley, J., Butlin, T. and Gill, S. (2018). Adapting cities to climate change-exploring the flood risk management role of green infrastructure landscapes. Journal of Environmental Planning and Management, 61(9), 1535-1552.

Chen, H., Ito, Y., Sawamukai, M. and Tokunaga, T. (2015). Flood hazard assessment in the Kujukuri Plain of Chiba Prefecture, Japan, based on GIS and multicriteria decision analysis. Natural Hazards, 78(1), 105- 
120.

Daura, M.M; Gisilanbe, A.M; \& Waziri M. (1997); Floodplain Encroachment and Hazard Awareness in Urbanized Catchments: A Study of Ngadda Floodplain in Maiduguri. In Ogunnika,O; Irefin,D; Daura,M \& Balami,D. (2001)Environment and Development Issues in Sub-Saharan Africa, Seminar Series, Vol.1. FSMS, University of Maiduguri. pp 50-60

Demir, V. and Kisi, O.; (2016) Flood hazard mapping by using geographic information system and hydraulic model: Mert River, Samsun, Turkey. Advances in Meteorology.

Deutsch, M. and Ruggles, F. (1974). Optical data processing and projected applications of the ERTS-1 imagery covering the 1973 Mississippi river valley floods. JAWRA Journal of the American Water Resources Association, 10(5), 1023-1039.

Dilley et.al 2005 in Bhuiyan, S. R. (2014). Flood hazard and vulnerability assessment in a riverine flood prone area a case study.

Dutta, D. and Herath, S. (2001, February). GIS based flood loss estimation modeling in Japan. In Proceedings of the US-Japan 1st workshop on comparative study on urban disaster management (pp. 151-161).

Emmanuel Udo, A., Ojinnaka, O. C., Baywood, C. N. and Gift, U. A. (2015). Flood hazard analysis and damage assessment of 2012 flood in Anambra State using GIS and remote sensing approach. American Journal of Geographic Information System, 4(1), 38-51.

Forkuo, E. K. (2011). Flood hazard mapping using Aster image data with GIS. International journal of Geomatics and Geosciences, 1(4), 932-950.

Singh, A. K. and Sharma, A. K. (2009). GIS and a remote sensing-based approach for urban flood-plain mapping for the Tapi catchment, India. IAHS publication, 331, 389

Gain, A. K. and Hoque, M. M. (2013). Flood risk assessment and its application in the eastern part of Dhaka city, B Bangladesh. Journal of flood risk management, 6(3), 219-228.

Govorushko, S. M. (2007). Effect of human activity on rivers.

Horritt, M. S., Mason, D. C., Cobby, D. M., Davenport, I. J. and Bates, P. D. (2003). Waterline mapping in flooded vegetation from airborne SAR imagery. Remote Sensing of Environment, 85(3), 271-281.

Imrul Hasan, S. M. (2006). Application of geoinformatics for flood study at Tarapur union of Gaibandha.

Jeyaseelan, A. T. (2003). Droughts \& floods assessment and monitoring using remote sensing and GIS. Satellite remote sensing and GIS applications in agricultural meteorology, 291. 
Jimme, M. A., Bashir, A. and Adebayo, A. A. (2016). Spatial distribution pattern and terrain analysis of urban flash floods and inundated areas in Maiduguri Metropolis, Borno State, Northeast, Nigeria. Journal of Geographic Information System, 8(01), 108.

Jonathan, A., Owolabi, M. T., Olatunji, I. B., Duntoye, B. T. and Henshaw, E. E. (2020). Economic analysis of the effect of flood disaster on food security of arable farming households in Southern Guinea Savanna Zone, Nigeria. Journal of Agriculture and Food Sciences, 18(1), 60-70.

Kaka, S. M., Mayomi, I. and Daura, M. M. (2019) Geospatial Assessment of the Impact of Topography on Flood Vulnerability in Maiduguri, Nigeria.

Karr, J.R. 1998. Rivers As Sentinels: Using the Biology of Rivers to Guide Landscape Management. In River Ecology and Management: Lessons from the Pacific Coastal Ecoregion, ed. R.J. Naiman and R.E. Bilby, 502-528. New York: Springer-Verlag.

Karr J.R., Chu E.W. (2000) Introduction: Sustaining living rivers. In: Jungwirth M., Muhar S., Schmutz S. (eds) Assessing the Ecological Integrity of Running Waters. Developments in Hydrobiology, vol 149. Springer, Dordrecht.

Klemas, V. (2015). Remote sensing of floods and flood-prone areas: an overview. Journal of Coastal Research, 31(4), 1005-1013.

Mala, M., Nyanganji, J. K. and Mukhtar, A. (2012). Gully development along River Ngaddabul floodplain of Maiduguri, Borno state, Nigeria. Journal of Environmental Issues and Agriculture in Developing Countries, 4(1), 45.

Mala, M.,Nyanganji, J. K. and Mukhtar, A. (2015). An Appraisal of Gully Erosion along River Ngaddabul Floodplain, Maiduguri, Borno State, Nigeria. Journal of Environment and Earth Science, 5(5), 1-8.

Mirza, M. M. Q. (2003). Climate change and extreme weather events: can developing countries adapt? Climate policy, 3(3), 233-248.

Moore, G. K. and North, G. W.; (1974). Flood inundation in the south-eastern United States from aircraft and satellite imagery 1. JAWRA Journal of the American Water Resources Association, 10(5), 1082-1096.

Nigeria Floods Sep 1994 UN DHA Situation Reports 1 - 3 Source UN DHA 22 Sep 1994

Nzeribe, G. E., Nwokoye, E. and Ezenekwe, U. (2014). What Implications does 2012 Flood Disaster have on the Nigerian Economy? Association of Energy and Environmental Economics of Nigeria-Nigerian Journal of Energy and Environmental Economics, 6(1), 15-28.

Oruonye, E. D. (2015). Assessment of the Socio-economic Impact of Kashimbilla Multipurpose dam Project in Takum LGA, Taraba State, Nigeria. Global Journal of Interdisciplinary Social Sciences, 4(5), 915. 
Rasid, H. and Pramanik, M. A. H. (1990). Visual interpretation of satellite imagery for monitoring floods in Bangladesh. Environmental Management, 14(6), 815-821.

Tingsanchali, T. (2012). Urban flood disaster management. Procedia engineering, 32, 25-37.

Wahlstrom and Guha-Sapir 2015 in Kabenge, M., Elaru, J., Wang, H. and Li, F. (2017). Characterizing flood hazard risk in data-scarce areas, using a remote sensing and GIS-based flood hazard index. Natural hazards, 89(3), 1369-1387.).

Wang, X. and Xie, H. (2018). A review on applications of remote sensing and geographic information systems (GIS) in water resources and flood risk management. Water, 10(5), 608

\section{Declarations}

Competing interest: The authors declare no competing interest exists.

\section{Figures}

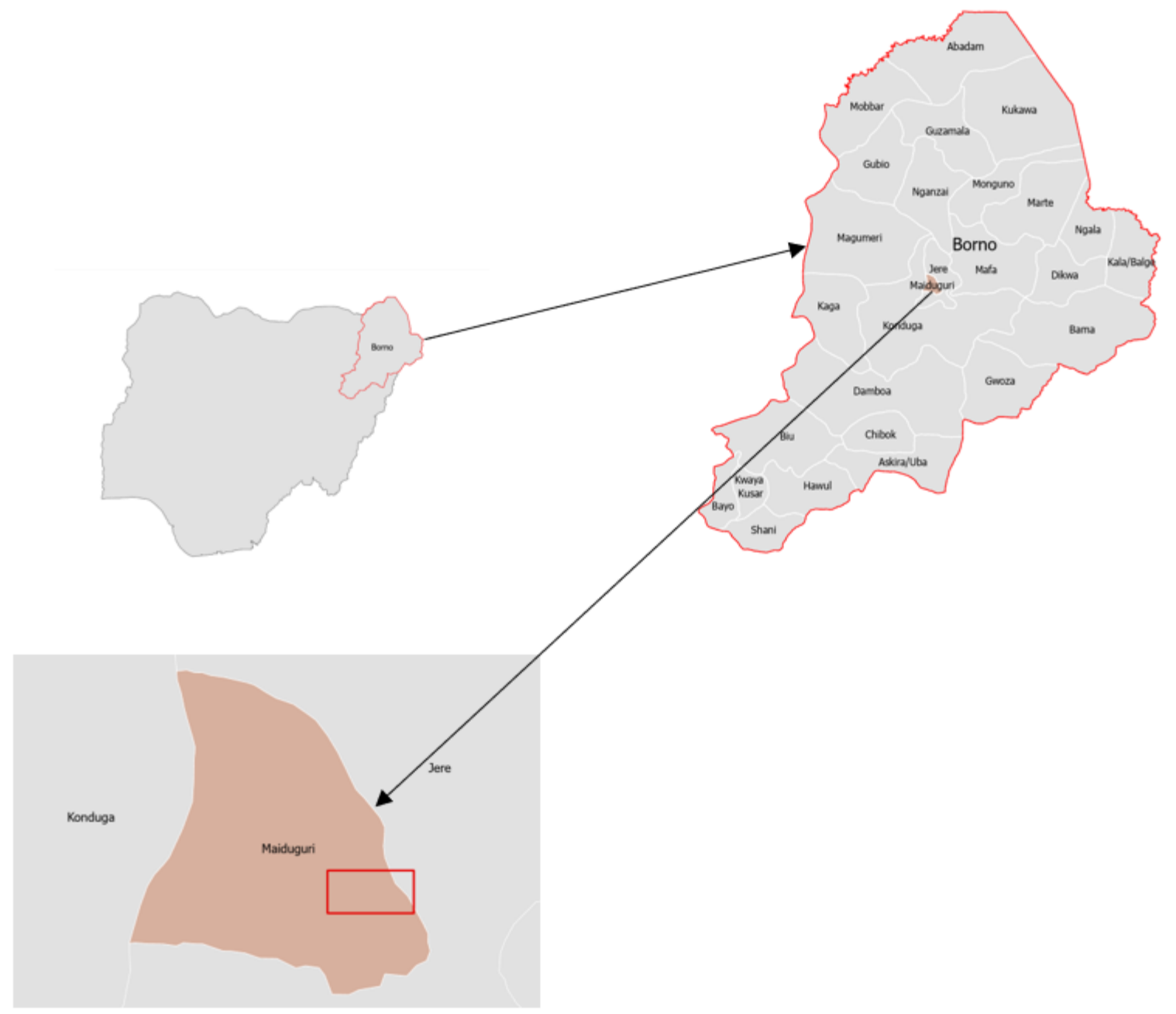


Figure 1

Figure 2.1: The Study area

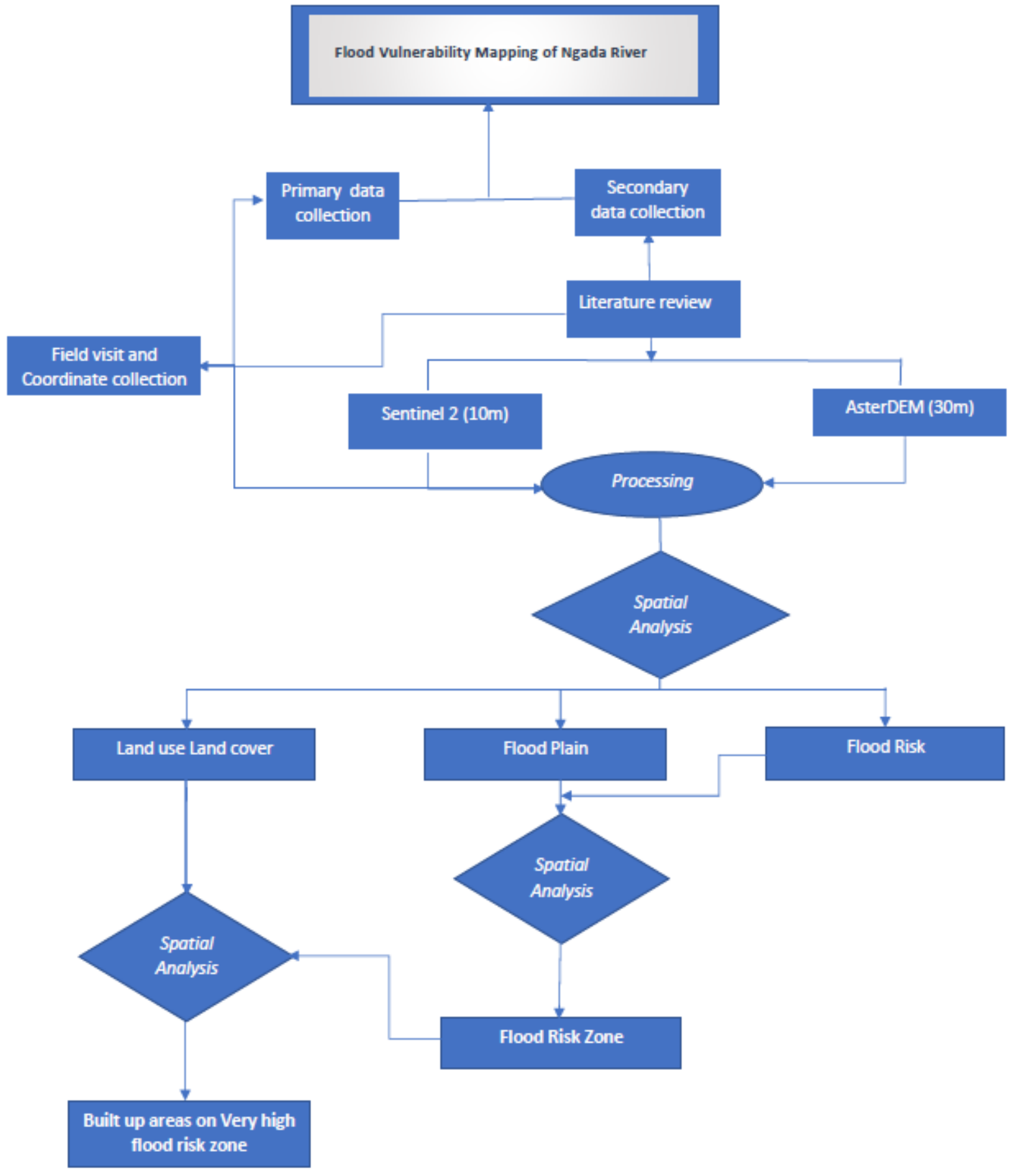

Figure 2

Figure 2.2: Flow chat of methodology 


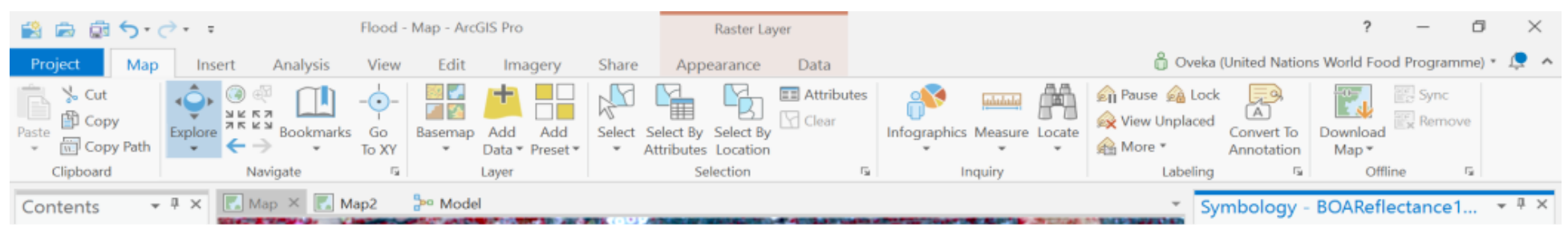

\section{Figure 3}

Figure 2.3 Sentinel-2 False color composite of River Ngadda

\section{Figure 4}

Figure 2.4 : AsterDEM of the study area with range values.

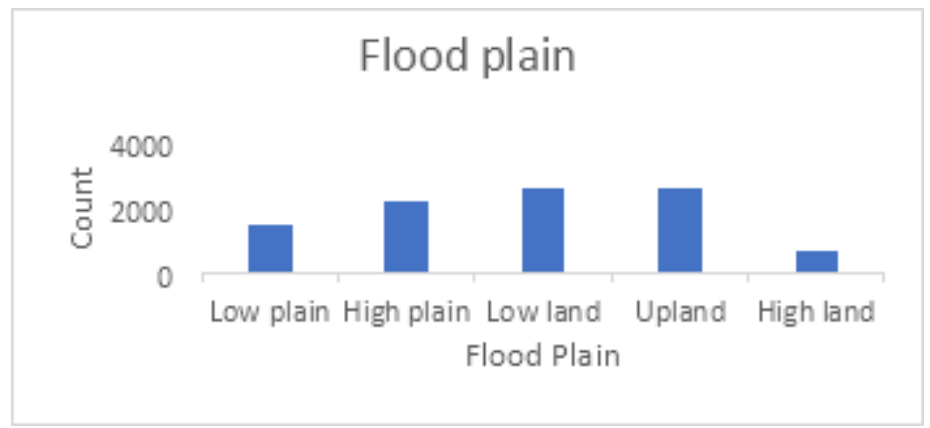

\section{Figure 5}

Figure 3.1: Flood plain analysis of River Ngadda 


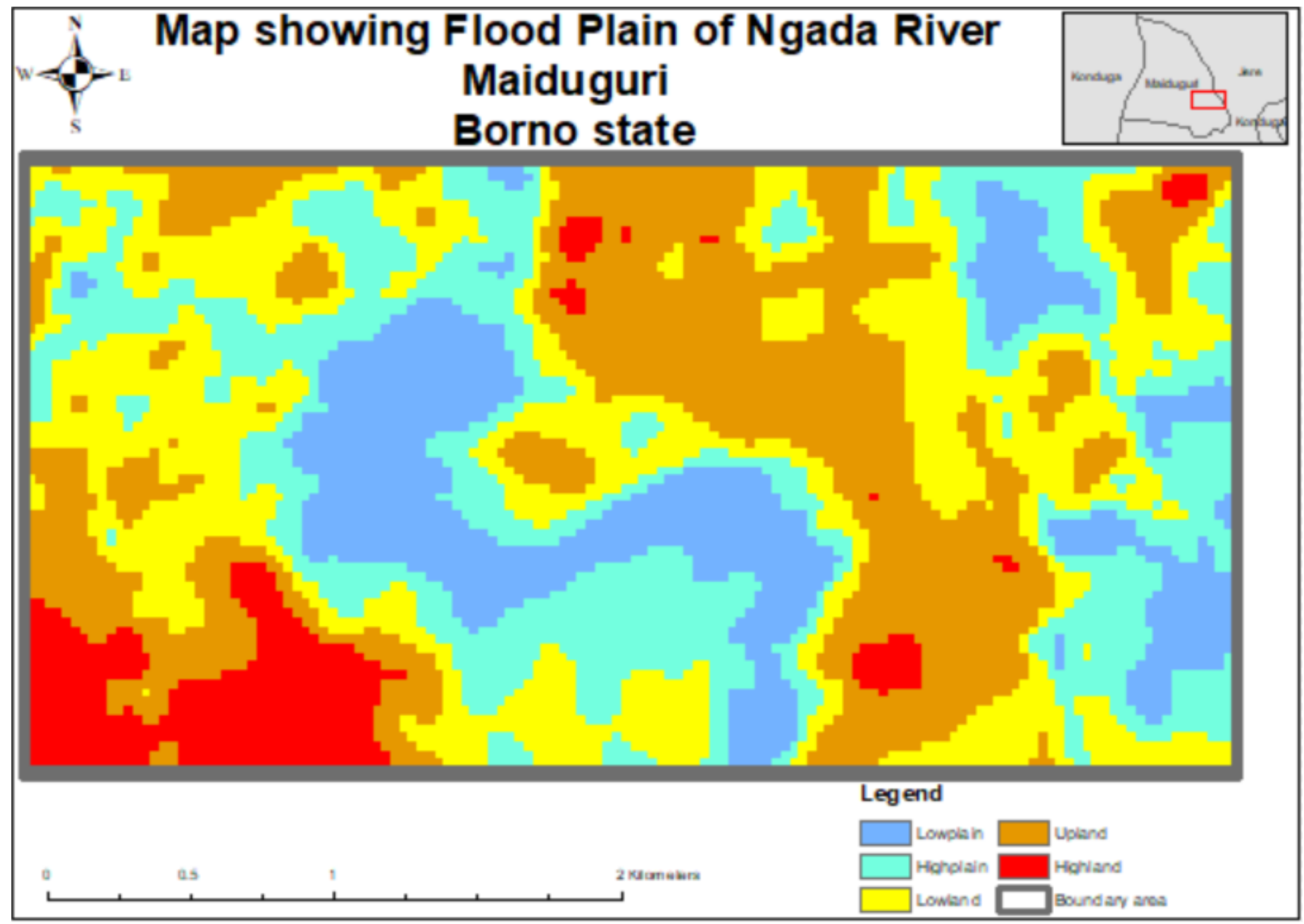

Figure 6

Figure 3.2 Flood plain spatial analysis and map of River Ngadda 


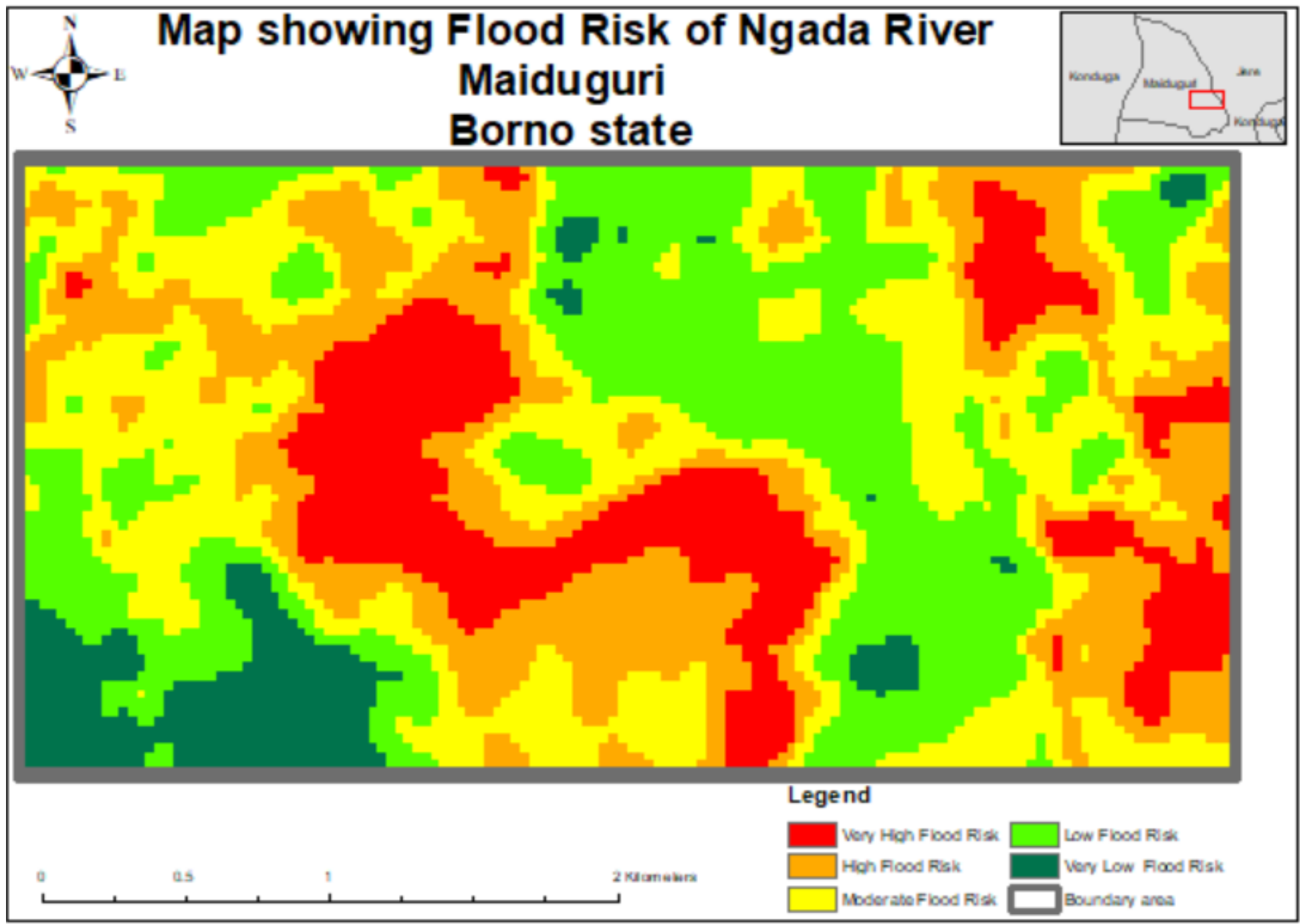

Figure 7

Figure 3.3. Flood risk map of River Ngadda 


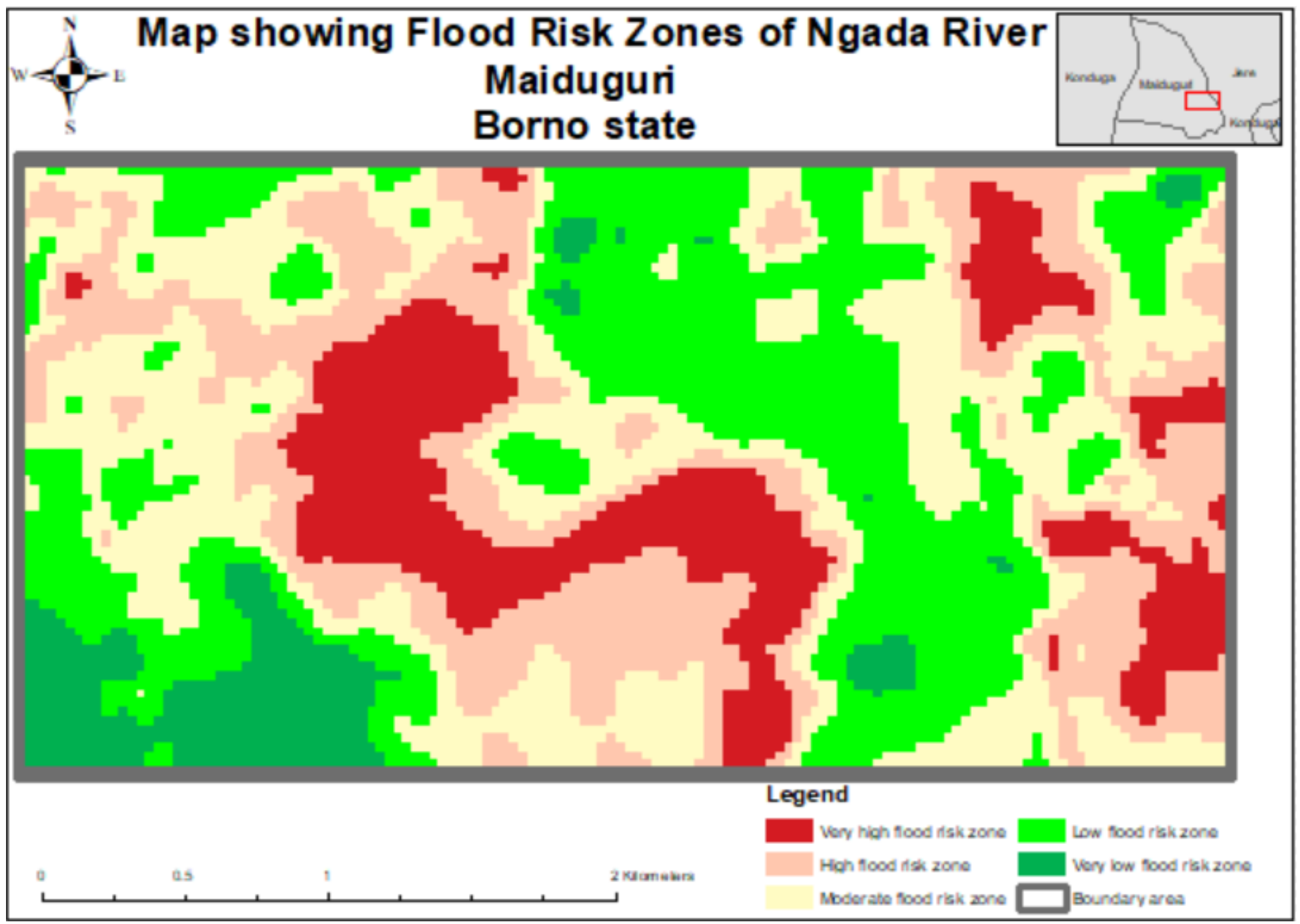

Figure 8

Figure 3.4 Flood risk zones of River Ngadda

Percentage of Flood Vulnerability Zones

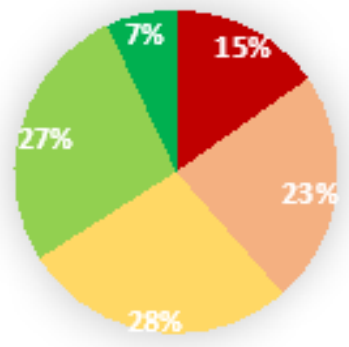

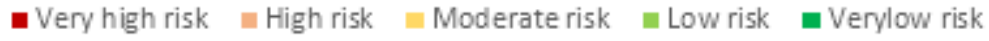

Figure 9 
Figure 3.5: Percentage of Flood vulnerability zone of River Ngadda

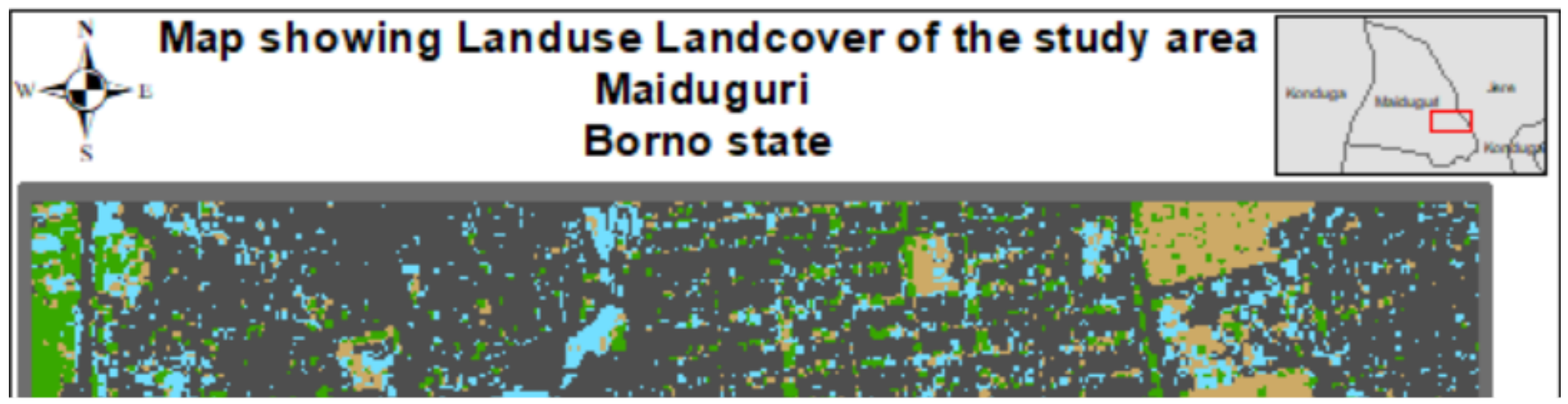

Figure 10

Figure 3.6: Land Use Land Cover map of River Ngadda 


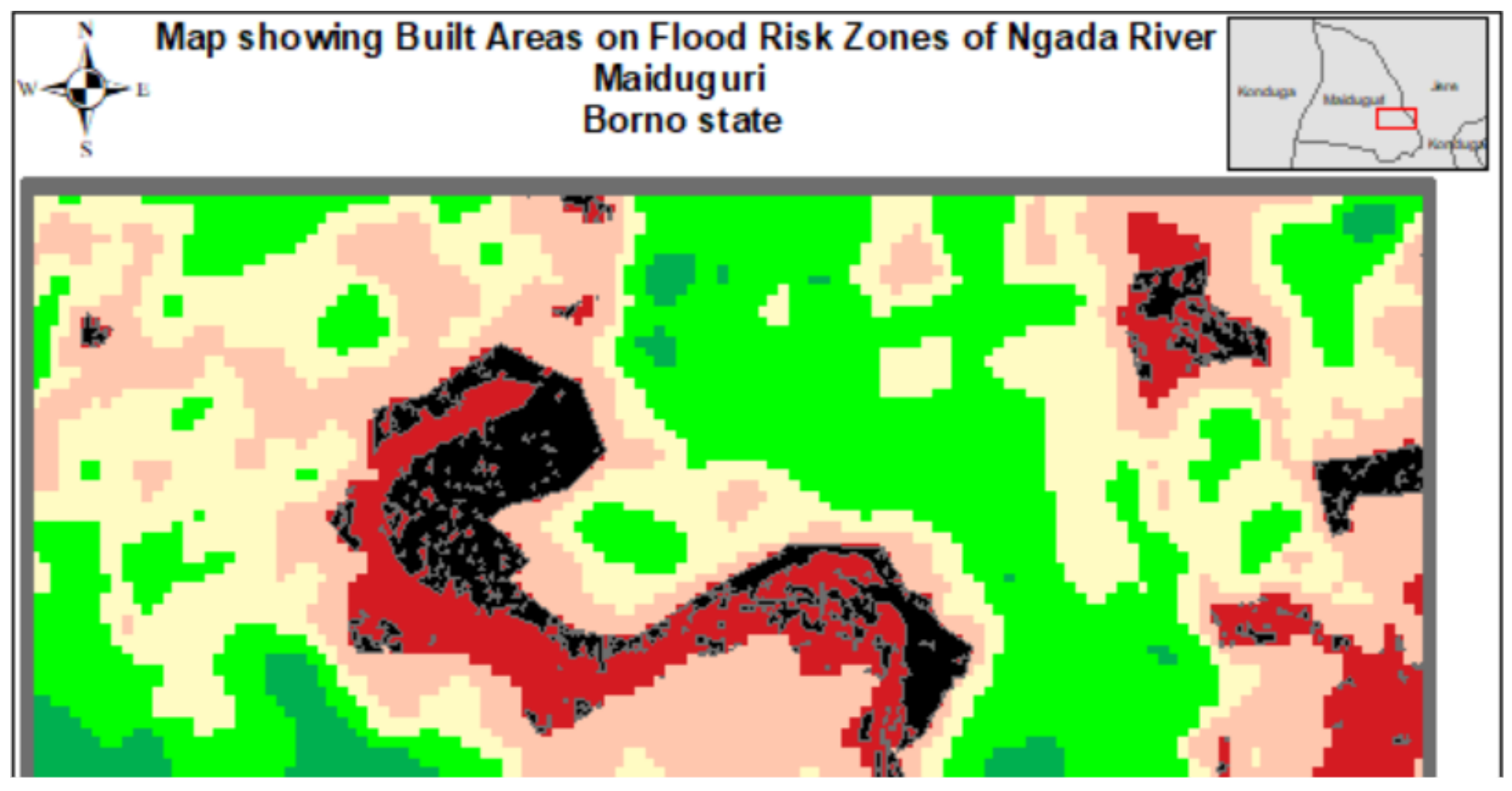

Figure 11

Figure 3.7. Built-up areas overlayed on the Very high flood risk zone of River Ngadda 